\title{
Playfulness in Lauren Child's Picture Books
}

\author{
Suzanne O’Sullivan
}

Lauren Child is the author/illustrator of thirteen picture books, four board books and three novels, most prominently the Clarice Bean series and the Charlie and Lola series. ${ }^{1}$ She has been feted as 'one of Britain's foremost children's writers and illustrators' (Booth 2005, p.13). As Rose notes, 'people rave about how clever the stories are, how the drawings and design are quirky and refreshingly different' (2006). Child has won numerous awards, including the Kate Greenaway Medal (for I Will Not Ever Never Eat a Tomato) and the Smarties Prize (for Clarice Bean, That's Me; What Planet Are You From, Clarice Bean? and That Pesky Rat).

One of the defining characteristics of Child's work is its playfulness. Playfulness is 'the principle of energy and difference which unsettles arrangements, promotes change and resists closure' (Edwards 1998, p.xiii), which 'affirms freedom and possibility against restriction, resignation and closure. Supporting open-endedness, it denies ontological anchors' (Edwards 1998, p.17). This principle is evident throughout Child's work, but particularly in her picture books, on which I will focus in this paper. Play 'has no purpose outside the activity as such, and therefore it is noninstrumentally oriented' (Volkwein 1991, p.363). Likewise, Child's picture books frequently resist linear readings, instead focusing on the process of reading and the pleasure of the moment as a reader encounters a text. Playful texts emphasise the role of the reader as creator: 'the text is viewed as a game affording both author and reader the possibility of producing endless meanings and relationships'(Mistacco 1980, p.375). In their playfulness, Child's picture books affirm the possibilities of the genre, continually inventing it anew.

Most of Child's picture books are illustrated using mixedmedia collage. Collage lends itself to playfulness by its nature, as it constructs a new image out of remnants of others. In doing so it mimics children's imaginative play, where 'a stick can serve as a gun; the instant convertibility of one thing into another is the very condition of play violence... Objects aren't even necessary. One can always point a finger as if it were a gun and emit shooting noises' (Brown 1999/2000, p.76). Child's images are constructed from multiple media: paintings (generally for backgrounds), naive drawings, fabric, photographs and digital media.
Collage gives a flatness to the image that draws attention to its constructedness. Doonan argues that 'collage always makes for a distinctive tension between illusion and reality, for it partakes of both by its very nature' (2001, p.183). By using collage, Child plays with readers' perceptions. From a very young age, children learn to read pictures, to identify, for example, a particular arrangement of line and colour as a human figure. By creating images out of several different materials - such as fabric over a line drawing over a watercolour background — Child draws attention to the image's materiality and forces the reader to perceive it as two things at once: both a human figure and an artwork. This polysemy again recalls children's imaginative play, where one object can stand in for another.

The use of photographs alongside drawings within collages further plays with reader perceptions and visual conventions. Photographs are seen as 'naturalistic, unmediated, uncoded representation[s] of reality' (Kress and van Leeuwen 1996, p.162) and in Western cultures constitute 'a kind of standard for visual modality' (1996, p.168). Within one double-page spread from I Am Not Sleepy and I Will Not Go to Bed ('And so Lola pops on her pyjamas', depicting siblings Charlie and Lola's bedroom) photographic images are used as framed images on the bedroom wall, as images in a book, as an appliqué on Charlie's pillow and as their toys (building blocks, a tea set, a basketball, a globe and a pinball game). The first two uses can be seen as a kind of playful reversal, where the secondary worlds of the children's books and pictures are more 'real' than the primary world of their bedroom. This diegetic instability is also evident in the juxtaposition of the photographic images in this secondary world with the photographic images in the primary world. The dog in the children's book and their building blocks have the same modality; it is only the fact that one is framed (by a drawn book page) that directs the reader to interpret the other as more 'real'.

By using photographic images for some objects and illustrations for others, Child plays with the reader's perception of the real. If, through identification with the characters, the reader perceives Charlie and Lola's world as 'real', the photographic detail of, for example, the building blocks 'becomes "hyper-real" and hence lower in modality' 
(Kress and van Leeuwen 196, p.166). This double-page spread is a space in which stable, centred structures are continually being destabilised and manipulated; a text which is not a closed, finite entity for readers to simply decode or consume, but one which they are positioned to engage with in a spirit of play.

Another material used in the 'Lola pops on her pyjamas' collage is fabric, the visual texture of which contrasts with the smoothness of the background and the photographic images. There are also variations, however, in how the fabric is presented. In some cases it appears that the fabric itself has been glued into the collage, as with the fringe on the rug. The bedspreads, in contrast, are constructed from colour photocopies of fabric, which creates an unusual mixture of texture and flatness. Readers familiar with Child's other books may recognise this fabric: it has variously been a lampshade (Beware of the Storybook Wolves), a butterfly (I Am Too Absolutely Small for School, Charlie and Lola's Numbers and Charlie and Lola's Opposites), an elephant (I Am Too Absolutely Small for School and Charlie and Lola's Numbers), wrapping paper (I Am Too Absolutely Small for School), a dress and a leaf (both in What Planet Are You From, Clarice Bean?). These recurring images engage readers in a textual game, encouraging them to view each book not as an enclosed universe, but as part of a wider field with recognisable conventions and patterns. Child further develops this textual game by quoting her own work: one of the posters on Lola's wall is the cover image from $I$ Want a Pet.

By drawing on a variety of media, Child's images mimic the expressive acts — such as play and speech — of children:

For children in their early, pre-school years there is both more and less freedom of expression: more, because they have not learnt to confine the making of signs to the culturally and socially facilitated media, because they are unaware of the established conventions and relatively unconstrained in the making of signs; less, because they do not have such rich cultural semiotic resources available as do adults.

(Kress and van Leeuwen 1996, p.7)
Child's unusual mixture of textures and modalities suggests that she makes use of the particular range of semiotic resources available; her promiscuous use of media and appropriation of different sign systems are unconstrained, open and freely inventive, affirming freedom and possibility.

The visual intertextuality of Child's collages recalls Barthes's assertion that every text is 'a new tissue of past citations. Bits of code, formulae, rhythmic models, fragments of social language, etc. pass into the text and are redistributed within it' (1981, p.39). As such, Child's picture books resist closed or fixed meaning, instead positioning themselves as part of a broader text. While visual intertextuality is found throughout Child's work, the stories of Beware of the Storybook Wolves and Who's Afraid of the Big Bad Book? are centred on intertextual play.

In Beware of the Storybook Wolves, the primary intertext is Little Red Riding Hood, which the protagonist Herb's mother reads to him before bed. One night she forgets to take the book with her when she leaves the room, and the two wolves (the wolf from Red Riding Hood and a 'smaller wolf with a patch over one eye' from an advertisement on the back cover) step out of the book and into Herb's room, promptly threatening to eat him. Herb enlists other fairy tale characters to help him escape from the wolves. In Storybook Wolves' sequel, Who's Afraid of the Big Bad Book?, Herb falls into a book of fairy tales, where he discovers that his interference with the physical book — such as drawing moustaches on characters and 'cut[ting] out the royal thrones for a model spaceship that he and Ezzie were making' - have disrupted the narrative. Herb's interventions recall Child's cut-and-paste, mixed media style, adding another layer of intertextuality to the book.

I earlier examined how Child's use of mixed-media collage complicates the reader's perception of her images, where objects supposedly within the same plane have different modalities. Child also resists the spatial boundaries of the text by having characters 'break through' the page into what Goldstone terms the fourth dimension - 'the space shared between the physical book and the reading/viewing audience' (2008, p.118) — and the fifth dimension — 'a spatial area that lies beneath the physical page' (2008, 
p.118). When Herb falls into his book of fairy tales in Big Bad Book, he enters this fourth dimension. While the reader had been reading a book about Herb's world, Herb has now entered into another space within that book, and has engaged in a new storyline. On the opening page of Big Bad Book the reader is told, 'Herb read his books everywhere. This was why many of the pages were stickily stuck together, soggy round the edges and usually had bits of banana, biscuit and the odd pea squashed between the pages.' On the same page, drink stains and a photographically reproduced squashed pea imply that the book the reader is holding is one of Herb's books, complicating the boundary between reader and character in an Escher-style puzzle. Similarly, when Herb is trapped in the fairy tale book, he cuts a hole in one page so that he can wriggle through onto the next; this page has a hole in one corner. The permeability of the boundaries between the physical book the reader is holding or viewing, Herb's world, and the storybook world Herb enters opens the text, denying readers the security of ontological anchors, but instead offering them freedom to engage with the text and to construct its meaning for themselves.

Nikolajeva and Scott argue that 'intertextuality presupposes the reader's active participation in the decoding process' (2001, p.228). One opening in Storybook Wolves shows the back cover of an edition of its intertext, Little Red Riding Hood, which features an advertisement for another book: 'For a real thrill try reading the story of The Little Fierce Wolf and the Three Pink Piglets. It will scare your socks off'. In this image, Herb occupies the position of the reader: we see only his hands holding the book. That is, he enters Goldstone's fourth dimension space and, like us, is outside the text. The reader is drawn into a textual game, compelled to make the connection between the back cover within the book and the back cover of the book, which begins, 'For a real thrill try reading Beware of the Storybook Wolves. It will scare your socks off'.

For this kind of playful interactivity to succeed, readers must be willing to play. Hans argues that a text 'can only be seen as playful ... if one is willing to accept the orientation it offers' (1981, p.viii). Playfulness is as much about the reader as the text—while a text may have qualities which make it playful, it is only if readers are willing to enter into play themselves that it truly becomes a playful text. For this reason children's literature and picture books in particular - written for an audience that is typically assumed to be inclined to play - lends itself to playfulness.

Critical writing about picture books almost always talks about them in terms of two parts: words and images. Lewis, for example, defines the picture book as 'a single text composed of two distinct media' (2001, p.3), and Mallan talks about picture books having 'two discourses, the verbal and the visual' (1999, p.27). This approach elides the fact that the verbal text, as the printed words on the page, is also a visual element, a semiotic system that must be decoded by the reader. Child's picture books make the verbal text's status as a visual element impossible to ignore by completely integrating it with the illustrations as part of the visual plane. The verbal text in Child's picture books is not merely functional; it has an aesthetic value.

Lewis argues that 'when we read picturebooks we look at the pictures and we read the words and our eyes go back and forth between the two as we piece together the meaning of the text' $(2001$, p.32). This statement is straightforward in the case of picture books where there is strict visual delineation between illustrations and words, for instance where the images are enclosed in solid frames and the words are positioned in the white space outside the frame, but Child's books typically make such distinctions more complicated. Words are frequently made to perform the dual role of language sign and illustrative element. Playful typography draws attention to the physical form of the words on the page, for example in Big Bad Book when the words 'Herb ran all the way through the forest' form the path along which Herb runs.

In Big Bad Book the typography also helps Herb to escape from Cinderella's wicked stepmother. The verbal text is arranged like a makeshift ladder, which Herb climbs, an act which firmly establishes that the illustration and the verbal text are occupying the same space. Picture book text, like speech balloons in comic books, is conventionally 'understood by readers and writers alike to belong to the telling-space. Exactly like the silent movie subtitle, it exists on the screen, on the flat surface of the page, and not in the story-space' (Pullman 1989, p.169). The visual interplay 
between words and illustration in Child's books destabilises the distinction between telling-space and story-space.

Child's picture books use unconventional typography to blur the distinction between the visual text and the verbal text, using the verbal text to create visual effects. In Clarice Bean, That's Me, for example, the leading is greatly reduced in the paragraph where Clarice describes how crowded her room is. 'My room is small so I have to squash everything in,' she says; likewise, these words are squashed together within a small space. Child also uses typography to imitate oral delivery, often giving each character their own 'voice' by setting their dialogue in a unique font. Cinderella's 'wickedly mean stepmother' in Big Bad Book, for example, has an ornate, script-style font that corresponds with her superciliousness and her extravagantly dressed, heavily made-up appearance. Herb himself, as focaliser, speaks in the same font that is used for the narration (albeit slightly larger), confirming his position at the centre of the text. For an adult reading the text aloud to a child (or children), these character fonts prompt them to use character voices, turning their reading into a performance. For an independent reader they mimic the experience of listening to a book being read aloud, by giving each character their own distinct 'voice'.

Child frequently uses typesetting that requires readers to turn the page on an angle — or even a full rotation - to read it. On one double-page spread from Hubert Horatio Bartle-Bobton Trent, the text describes the complicated path Hubert takes through the family mansion to reach his parents' bedroom. In order to read this text, readers must turn the book to a different angle every few words, mirroring Hubert's journey. This typography pushes the boundaries of two-dimensional representation to depict a movement in three-dimensional space. It unsettles the established conventions of reading, forcing the reader to engage with the text as a physical object.

Earlier in this paper I discussed the inherent playfulness of mixed-media collage. Child's use of text-as-image — the integration of typography into the illustrations, and even into the story - can be seen as another element in these collages. Bland argues that illustrations in perspective are problematic for designers, who must attempt to 'reconcile the flatness of the text with the depth of the picture' (quoted in Nodelman 1988, p.56). By using collage to give a flatness to her illustrations, Child reduces the perceptual gap between words and illustration, allowing the reader to perceive them as elements of a whole image.

Scieszka and Leach argue that good design, 'the subtle weave of words and pictures that allows both to tell one seamless tale ... is, by its very nature, nearly invisible in the final product'(1998, p.196-97). That is, a successful design should appear natural — the reader should unconsciously feel that the type used is the right one for the text, that the illustrations and words have been arranged exactly as they should be. Child's picture books, rather than attempting to appear 'natural', foreground their constructedness through design which pushes boundaries and resists rules.

Child has said that the unconventional design of her books stems from 'not knowing all the rules ... perhaps not knowing means you fumble your way through it and you get something different' (quoted in Ridge 2003), echoing Lewis's statement that 'writers and illustrators of picturebooks address an audience for whom what counts as reading and what can legitimately go into a book are concepts that are still being learned' (2001, p.77). Rather than taking certain conventions as sacrosanct, she has played with them: extending the text beyond its conventional boundaries, affording typography the same visual status as illustration, and extravagantly mixing visual media. As a result, her work is characterised by a sense of open and free expression, exploring the possibilities of the picture book form.

The first opening of Clarice Bean, That's Me is typical of Child's work in several ways. The first of these is the way it plays with picture book conventions. Where one would normally find the imprint (publication details) and title pages, That's $M e$ instead launches straight into the narrative. Thus from the very beginning the reader's expectations are unsettled; rather than the conventional label(title page) and marker of the book-as-product (imprint page), the reader is faced with a multifaceted image that delights in excess.

One critic has described Child's picture books as 'in-yourface graphic scrapbooks' (Wyile 2006, p.194), and this 
opening epitomises that definition. The image shows twelve people (and two animals) crowded around a large table. The illustrative style is typical of naïve art in that it is 'childlike and can be characterised by a lack of perspective. Figures are simplified so that they often take on a symbolic rather than a real appearance. Brushstrokes are usually vigorous, energetic, free, expressive and spontaneous' (Mallan 1999, p.52). Although I have used words like 'chaos' and 'naïve', this opening has in fact been carefully composed to create a sense of busy-ness and crowded space. This includes the setting of the primary verbal text. Arranged at angles around the illustration, it gives an impression of squeezing in, of trying to find space in an overcrowded room. Thus even before readers have read any of the verbal text they have grasped the essence of the information that this spread is conveying: a house full of people 'always at sixes and sevens' (Child 1999a), where peace and quiet are hard to find.

Several things are evident in a close reading of the opening spread of That's Me. The first is the use of a secondary verbal text: handwritten captions labelling each figure. The use of words within the image blurs the distinction between the two fields and evokes associations with cartoons. The label on one figure, 'I don't know who this is', reinforces the sense of chaos implied by the composition of the image and also makes a distinction between the verbal narrator (Clarice Bean) and the apparently omniscient visual narrator. It puts distance between the reader and the image, as the fictional character Clarice has been the first reader of the image and has labelled it. This metalepsis is a form of 'play, [which] in its inclusiveness and openness, and in its disestablishment of restrictive hierarchies, emphasizes activity that becomes, in its turn, part of a potentially infinite discourse' (Edwards 1998, p.30). Just as Clarice has been a reader of the text, so each reader is inscribed as a participant in its creation.

With limited use of perspective and no clear vectors, readers have no cues as to where to direct their attention. The image has no obvious focal point, compelling readers to study the image closely, breaking it down into its parts, rather than viewing it as a whole. The 'overwhelming pictorial demands' (Wyile 2006, p.194) of images like this slow down the reading process, compelling readers to explore the image, to be diverted from the linear narrative. Reading such an image is thus a form of play, as readers are drawn into 'a festive display of accumulation over balance' (Stewart, quoted in Lewis 1990, p.144) and given licence to explore the image in whatever way they wish. It challenges the notion of an authoritative discourse, instead privileging reading as a creative act in which each reader produces the text. It mimics the process whereby 'one exteriorizes himself in play and ... [realises] the possibilities of imagination' (Wilson 1986, p.83).

There is no 'correct' way to read this double-page spread. The reader could simply read the primary verbal text and briefly scan the image; they could study the image closely and read every caption before reading the primary verbal text, or vice versa; they could read only some of the captions, perhaps keeping something in reserve for a later reading. This openness gives the image a sense of immediacy that evokes the spontaneity of play, which is always in flux and can change course at any moment. Play is inherently an action; it is something that exists in the moment and is always transforming and creating itself. A child may play with the same doll hundreds of times, but the play will be slightly different in each instance. Typical of Child's picture books, That's Me evokes this spontaneity by encouraging readers to read the text in a slightly different way each time.

Child has recounted how That's Me took shape when an editor pulled together several disparate illustrations to create a narrative (Ridge 2003, Rabinovitch 2003). Each opening in That's Me is, like the opening spread, a vignette capturing a particular scene, with details to be explored; the overarching plot is secondary to the enjoyment of each of these moments. All pictures books are, on one level, a series of individual artworks arranged in a sequence. Rather than eliding this by emphasising the plot connecting these individual artworks, Child encourages readers to linger over each one, emphasising process over product. All of Child's picture books are similarly engaged in a constant play with conventions, examining and subverting how texts are constructed and read. They are books in which boundaries - between texts, within texts, and between readers and texts - are constantly being breached. Their approach is one of playful spontaneity and exploration, 
giving the impression not just of a text being created anew with each reading, but of a genre being continually reimagined.

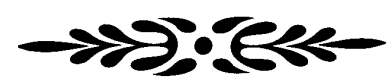

\section{NOTES}

1. There are also many books produced in association with the Charlie and Lola television series which, although they have Child's name on the cover, feature her characters and follow her visual style, are not actually written by her and are thus beyond the scope of this paper. Also not discussed here are works by other authors which Child has illustrated.

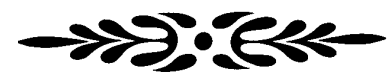

\section{REFERENCES}

Barthes, Roland (1981) 'Theory of the text' in Robert Young (ed) Untying the Text: A Post-structuralist Reader. London, Routledge, pp.131-161.

Booth, Hannah (2005) 'Profile: Lauren Child' Design Week 28 July 2005: 13.

Brown, Gillian (1999/2000) 'Child's play', differences: A Journal of Feminist Cultural Studies 11.3: 76-106.

Child, Lauren (1999a) Clarice Bean, That's Me. London, Orchard Books.

-(1999b) I Want a Pet. London, Frances Lincoln.

-(2001a) I Am Not Sleepy and I Will Not Go to Bed. London, Orchard Books.

- (2000b) I Will Not Ever Never Eat a Tomato. London, Orchard Books.

- (2001b) What Planet Are You From Clarice Bean?. London, Orchard Books.

- $(2000 \mathrm{c})$ Beware of the Storybook Wolves. London, Hodder Children's Books.
Child, Lauren (2002b) That Pesky Rat. London, Orchard Books.

(2002c) Who's Afraid of the Big Bad Book? London, Hodder Children's Books.

-(2003) I Am Too Absolutely Small for School. London, Orchard Books.

- (2004b) Hubert Horatio Bartle Bobton-Trent. London, Hodder Children's Books.

- (2007c) Charlie and Lola's Numbers. London, Orchard Books.

(2007d) Charlie and Lola's Opposites. London, Orchard Books.

Doonan, Jane (2001) 'At the cutting edge: Picturebooks by Sara Fanelli and Bruce Ingman', Signal 96: 181-198.

Edwards, Brian (1998) Theories of Play and Postmodern Fiction. New York, Garland Publishing, Inc.

Goldstone, Bette (2008) 'The paradox of space in postmodern picturebooks' in Lawrence R. Sipe and Sylvia Pantaleo (eds) Postmodern Picturebooks: Play, Parody and SelfReferentiality. New York, Routledge, pp.117129.

Hans, J. S. (1981) The play of the world. Amherst, MA, University of Massachusetts Press.

Kress, Gunter and Theo van Leeuwen (1996) Reading Images: The Grammar of Visual Design. London, Routledge.

Lewis, David (1990) 'The constructedness of texts: picture books and the metafictive', Signal 62: 131-147.

_-(2001) Reading Contemporary Picturebooks: Picturing Text. London, Routledge/ Falmer.

Mallan, Kerry (1999) In the Picture: Perspectives on Picture Book Art and Artists. Wagga Wagga, Centre for Information Studies, Charles Sturt University. 
Mistacco, Vicki (1980) 'The theory and practice of reading nouveaux romans: Robbe-Grillet's Topologie d'une Cité Fantôme' in Susan R. Suleiman and Inge Crossman (eds) The Reader in the Text. Guildford, Princeton University Press, pp.371-400.

Nikolajeva, Maria and Carol Scott (2001) How Picturebooks Work. London, Garland.

Nodelman, Perry (1988) Words About Pictures: The Narrative Art of Children's Picture Books. Athens and London, University of Georgia Press.

Pullman, Philip (1989) 'Invisible pictures', Signal 60 pp.160-186.

Rabinovitch, Dina (2003) 'Author of the month: Lauren Child' Guardian 24 September 2003. http://books.guardian.co.uk/departments/ childrenandteens/story/0,6000,1048732,00.html Accessed 21/6/08.

Ridge, Judith (2003) 'Interview with Lauren Child'. http://www.misrule.com.au/laurenchild1.html. Accessed 21/6/08.

Rose, Hilary (2006) 'Child's Play', Times Online 21 October 2006, published online at $<\mathrm{http}$ :/ women.timesonline.co.uk/tol/life and style/ women/families/article606327.ece>
Scieszka, Jon and Molly Leach (1998) 'Design matters', The Horn Book Magazine March/ April: 196-208.

Volkwein, Karin A.E. (1991) 'Play as a path for liberation: a Marcusean perspective', Play \& Culture 1.4: 359-370.

Wilson, Robert R. (1986) 'Play, transgression and carnival: Bakhtin and Derrida on Scriptor Ludens', Mosaic 19:1 (Winter): 73-89.

Wyile, Andrea Schwenke (2006) 'The drama of potentiality in metafictive picture books: engaging pictorialization in Shortcut, Ooh-la-la, and Voices in the Park (with occasional assistance from A. Wolf's True Story)', Children's Literature Association Quarterly 31.2: 176-196.

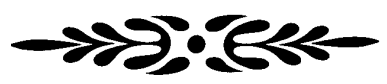

\section{BIOGRAPHICAL NOTE}

Suzanne O'Sullivan is a children's book editor. She has an MA in Children's Literature from Macquarie University. 